\title{
THE EFFECTS OF CHLORINE INTAKE ON SOME MORPHOMETRIC PARAMETERS OF THE THYROID GLAND IN LAMBS
}

\author{
M. KÓŇOVÁ ${ }^{1}$, E. BÉKEOVÁ ${ }^{2}$, M. LEVKUT ${ }^{1}$ \\ ${ }^{1}$ Department of Pathological Anatomy, University of Veterinary Medicine and \\ ${ }^{2}$ Institute of Experimental Veterinary Medicine, Košice, Slovak Republic \\ Received November 30, 1998 \\ Accepted June 28, 1999
}

\begin{abstract}
Kóňová M., E. Békeová, M. Levkut: The Effects of Chlorine Intake on Some Morphometric Parameters of the Thyroid Gland in Lambs. Acta Vet. Brno 1999, 68: 191-195.

The aim of the study was to determine whether drinking water containing two concentrations of chlorine $\left(0.3 \mathrm{mg} \cdot \mathrm{l}^{-1}\right.$ or $\left.1.8 \mathrm{mg} \cdot \mathrm{l}^{-1}\right)$ affects morphometric indicators of follicular epithelial cells and the diameter of thyroid gland follicles in young lambs.

The height of follicular epithelial cells, the diameter of thyroid gland follicles, the frequency of epithelial cell height categories, and the frequency of follicular diameter categories were studied in two groups of lambs after two treatments: one for four weeks and the other for three months. The first group had access to drinking water with $0.3 \mathrm{mg} \cdot \mathrm{l}^{-1}$ chlorine (short-term intake and low $\mathrm{Cl}$ concentration) for four weeks. The second group had access to drinking water containing $1.8 \mathrm{mg} \cdot \mathrm{l}^{-1}$ chlorine (long-term intake and high concentration) for three months.

A significant increase $(\mathrm{P}<0.01)$ in follicular epithelial cell height and a significant frequency distribution shift to the higher cellular height categories was observed after intake of chlorinated water $\left(0.3 \mathrm{mg} \cdot \mathrm{l}^{-1}\right),(\mathrm{P}<0.01$ for cell height categories 3.1-4 and 4.1-5 $\mu \mathrm{m})$ for four weeks. There was also a significant shift $(\mathrm{P}<0.01$ for cell height categories $4.1-5$ and $5.1-6 \mu \mathrm{m})$ in lambs receiving $1.8 \mathrm{mg} \cdot \mathrm{l}^{-1}$ chlorine in their drinking water for three months as compared to controls.

The diameter of thyroid gland follicles significantly decreased $(\mathrm{P}<0.01)$, and the percent of small thyroid follicles significantly increased (for diameter categories 20.1-40 and 40.1-60 $\mu \mathrm{m}$ $\mathrm{P}<0.01$ and $\mathrm{P}<0.05$, respectively) in lambs receiving $1.8 \mathrm{mg} \cdot \mathrm{l}^{-1}$ chlorine in drinking water for three months as compared to controls.

Our morphometric findings suggest that chlorine interferes with the thyroid metabolism in lambs, however, with no macroscopically detectable changes of the thyroid.
\end{abstract}

Follicular epithelial cell, follicle, cell height, follicular diameter

The size and function of the thyroid gland is subject to feed-back control mechanisms. Whenever the hormonal secretion of the thyroid decreases such as with the disturbance of iodine metabolism or an intake of antithyroid substance or goitrogen, the secretion of the hormone thyrotropin (TSH) increases and elicits proliferation and differentiation of the thyroid gland cells (Dumont 1993). Nowadays, the environmental pollution reduces the accessibility of iodine for animals and/or decreases the hormonal synthesis in the thyroid gland. Soils in Central Europe are relatively poor in iodine (Anke et al. 1993) and produce feeds that do not ensure a sufficient intake of iodine for animals. The natural plant goitrogens occur in several kinds of plant foods in variable amounts and likely goitrogens occur in water sources (Zrůnek et al. 1989; Gaitan 1990; Písaříková et al. 1996). Xenobiotics continually contaminate the environment. A considerable number of these pollutants are anthropogenic goitrogens or antithyroid substances (Gaitan 1990; Capen et al. 1991). All these factors together act against the synthesis and metabolism of thyroid gland hormones.

The disinfection of potable water with chlorine-based disinfectants represents the most dominant class of inorganic xenobiotics ingested continuously (Bercz and Garner 
1991). The chlorine-based disinfectants have been reported occasionally to affect the endocrine homeostasis and thyroid hormone levels in blood in animals.

The purpose of this study was to determine whether drinking water containing chlorine at a concentration of $0.3 \mathrm{mg} \cdot \mathrm{l}^{-1}$ or at a concentration of $1.8 \mathrm{mg} \cdot \mathrm{l}^{-1}$ would affect the height of follicular epithelial cells and the diameter of follicles in the thyroid gland of healthy lambs.

\section{Materials and Methods}

Slovak Merino lambs (age 2 months) were observed for 14 days prior to treatment. The lambs were fed with the standard feed mixture ČOJ 2 (250-300 g per day and per lamb, containing 80 and $96 \mu \mathrm{g}$ of iodine, respectively) and meadow hay ( $350 \mathrm{~g}$ per day and per lamb). The feed was grown in a nongoitrogenic area.

The drinking water for the experimental groups was chlorinated with gas chlorine and contained chlorine at a concentration of $0.3 \mathrm{mg} \cdot \mathrm{l}^{-1}$ or $1.8 \mathrm{mg} \cdot \mathrm{l}^{-1}$. It was adjusted with sodium hypochlorite and was changed daily. Lambs were divided in two groups: one group (Low Short-term group, $n=3$ ), was offered water with $0.3 \mathrm{mg} \cdot \mathrm{l}^{-1}$ chlorine for 4 weeks, and the second group (High Long-term group, $\mathrm{n}=4$ ) was given water containing $1.8 \mathrm{mg} \cdot \mathrm{l}^{-1}$ chlorine for 3 months The intake of chlorinated water per day and lamb was 0.81 in the low short-term group and $0.8,1.2$ and 1.61 during succesive months in the high long-term group. Animals of the control groups for low intake $(\mathrm{n}=3)$ and for high intake $(\mathrm{n}=4)$ were given spring drinking water, which was changed daily.

The samples of both thyroid gland lobules of all 14 animals were collected from the inner part of the gland immediately after sacrificing. The samples were fixed in 10\% buffered (phosphate) formalin, embedded in paraffin, cut at a thickness of about $5 \mu \mathrm{m}$ and stained with haematoxylin and eosin (HE). The morphometric measurements were made with a calibrated screw micrometer. The height of 100 follicular epithelial cells and the diameter of 100 gland follicles from each sample and each animal was measured at a magnification of $400 \times$.

The results are expressed as means \pm SEM or the frequency of cellular height and follicular diameter categories in percent. The data for each parameter was subjected to statistical analysis. First the variance of the two groups was compared using the preliminary $F$ test and if it suggested that a significant difference of the means existed, then the two - tailed $z$ test comparing two means and comparing two proportions with $\alpha=0.05$ was used and the $\mathrm{P}$ value was found by using the table of $z$ distribution (Triola 1989). Significance was considered when the probability value $(\mathrm{P})$ was less than 0.05 .

\section{Results}

The height of follicular epithelial cells of the thyroid gland in lambs significantly $(\mathrm{P}<0.01)$ increased after chlorinated water intake at $0.3 \mathrm{mg} \cdot \mathrm{l}^{-1}$ chlorine, $(3.387 \pm 0.0493 \mu \mathrm{m})$ and at $1.8 \mathrm{mg} \cdot \mathrm{l}^{-1}$ chlorine $(3.948 \pm 0.0780 \mu \mathrm{m})$ as compared to controls $(2.837 \pm 0.0413$ and $2.905 \pm 0.0598 \mu \mathrm{m}$, respectively), see Fig. 1 .

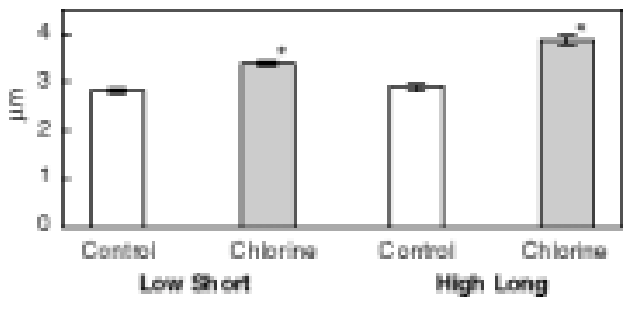

Fig. 1. Follicular epithelial cell height of the thyroid gland in $\mu \mathrm{m}$ after intake of chlorinated water at $0.3 \mathrm{mg} \cdot \mathrm{l}^{-1}$ for 4 weeks (low short-term) and after intake of chlorinated water at $1.8 \mathrm{mg} \cdot \mathrm{l}^{-1}$ for 3 months (high long-term). Values are means \pm SEM. The asterisk indicates significant differences between the respective chlorine and control groups $* \mathrm{P}<0.01$.

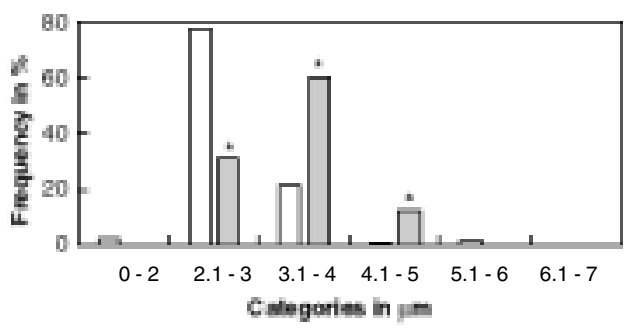

Fig. 2. The frequency of follicular epithelial cell height categories of the thyroid gland as percent after intake of chlorinated water at $0.3 \mathrm{mg} \cdot \mathrm{l}^{-1}$ for 4 weeks. The white column - control, the grey column - chlorine group. The asterisk indicates significant differences between the respective chlorine and control groups $* \mathrm{P}<0.01$

The frequency distribution of the follicular epithelial cell height significantly shifted to the higher height categories ( $\mathrm{P}<0.01$ for categories $3.1-4$ and $4.1-5 \mu \mathrm{m}$ ) after intake of 
chlorinated water at $0.3 \mathrm{mg} \cdot \mathrm{l}^{-1}$ chlorine ( Fig. 2 ), and also significantly shifted $(\mathrm{P}<0.01$ for categories 4.1-5 and 5.1-6 $\mu \mathrm{m}$ ) after intake of chlorinated water at $1.8 \mathrm{mg} \cdot \mathrm{l}^{-1} \mathrm{chlorine}$ (Fig. 3).

The diameter of thyroid gland follicles did not change after chlorinated water intake at $0.3 \mathrm{mg} \cdot \mathrm{l}^{-1}$ chlorine $(75.75 \pm 2.14 \mu \mathrm{m})$ as compared to controls $(74.88 \pm 1.65 \mu \mathrm{m})($ Fig. 4$)$. The diameter of follicles significantly decreased $(\mathrm{P}<0.01)$ after chlorinated water at $1.8 \mathrm{mg} \cdot \mathrm{l}^{-1}$ chlorine $(48.50 \pm 1.55 \mu \mathrm{m})$ as compared to controls $(70.89 \pm 1.54 \mu \mathrm{m})$, see Fig. 4 .

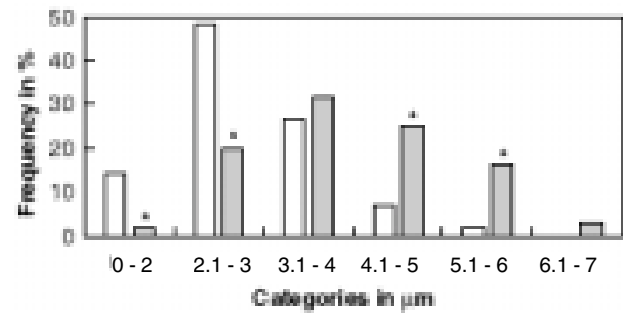

Fig. 3. The frequency of follicular epithelial cell height categories of the thyroid gland as per cent after intake of chlorinated water at $1.8 \mathrm{mg} \cdot \mathrm{l}^{-1}$ for 3 months. The white column - control, the grey column - chlorine group. The asterisk indicates significant differences between the respective chlorine and control groups $* \mathrm{P}<0.01$.

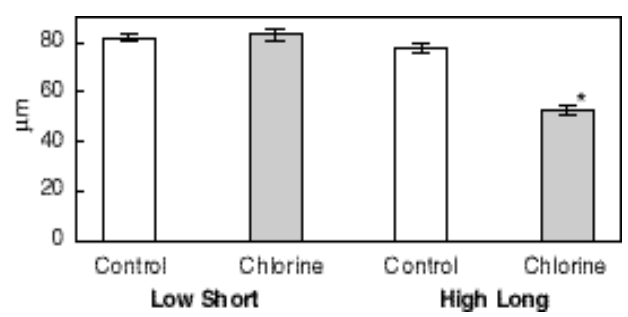

Fig. 4. Follicular diameter of the thyroid gland in $\mu \mathrm{m}$ after intake of chlorinated water at $0.3 \mathrm{mg}^{-1} \mathrm{l}^{-1}$ for 4 weeks (low short-term) and after intake of chlorinated water at $1.8 \mathrm{mg}^{\cdot} \mathrm{l}^{-1}$ for 3 months (high long-term). Values are means \pm SEM. The asterisk indicates significant differences between the respective chlorine and control groups $* \mathrm{P}<0.01$.

The frequency of the follicular diameter categories of the thyroid gland expressed as percent did not change after chlorinated water intake at $0.3 \mathrm{mg} \cdot \mathrm{l}^{-1}$ chlorine (Fig. 5). The frequency of the follicular diameter categories of the thyroid gland in percent significantly $(\mathrm{P}<0.01$ and $\mathrm{P}<0.05$, respectively) shifted to the smaller diameter categories, to 20.1-40 $\mu \mathrm{m}(40 \%)$ and to $40.1-60 \mu \mathrm{m}(29.5 \%)$, after chlorinated water intake at chlorine concentration of $1.8 \mathrm{mg} \cdot \mathrm{l}^{-1}$ as compared to controls (11.0 and $20.0 \%$, respectively), i. e. the number of small and smaller follicles increased (Fig. 6 ).

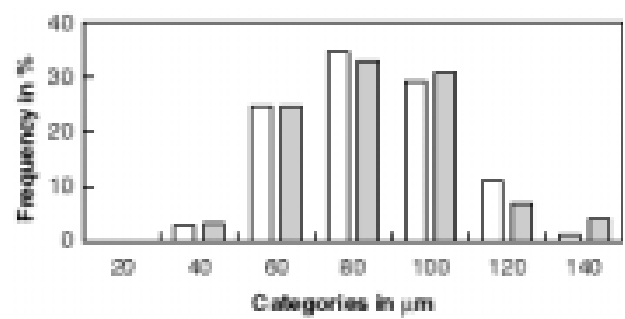

Fig. 5. The frequency of follicular diameter categories of the thyroid gland in per cent after intake of chlorinated water at $0.3 \mathrm{mg} \cdot \mathrm{l}^{-1}$ for 4 weeks. The white column - control, the grey column - chlorine group. The differences between the respective chlorine and control groups were not significant.

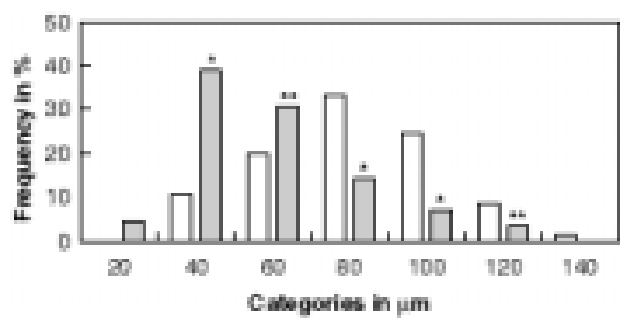

Fig. 6. The frequency of follicular diameter categories of the thyroid gland in per cent after intake of chlorinated water at $1.8 \mathrm{mg} \cdot \mathrm{l}^{-1}$ for 3 months. The white column - control, the grey column - chlorine group. The asterisk indicates significant differences between the respective chlorine and control groups $(* \mathrm{P}<0.01$, $* * \mathrm{P}<0.05)$.

The shape of follicles was regular without protruding follicular cells into the lumen of follicles. Changes in the macroscopical size of all thyroid glands were not seen. 


\section{Discussion}

Both the short-term consumption of drinking water containing $0.3 \mathrm{mg} \cdot \mathrm{l}^{-1} \mathrm{chlorine}$ and the long-term consumption of water with $1.8 \mathrm{mg} \cdot \mathrm{l}^{-1}$ were associated with a significant increase in follicular epithelial cell height and a significant frequency distribution shift to the higher height categories. These results suggest antithyroidal effects of chlorine or chlorinated products formed when chlorine reacts with organic matter in the upper gastrointestinal tract as it is presumed in pigeons (Revis et al. 1986) or the effects of some iodinated molecule forming in trace quantities in the alimentary tract responsible for the thyroid inhibition during chlorine dioxide exposure (Bercz et al. 1986). It has also been shown (Bercz et al. 1982; Orme et al. 1985) that decreased serum thyroxin levels occur in monkeys and neonatal rats during subchronic exposure to chlorine dioxide in drinking water. A significant frequency distribution shift to the smaller follicle categories suggests an increase in the activity of the thyroid gland and/or multiplication of smaller and probably more active follicles.

Our morphometric results suggest the interference of chlorine with thyroid metabolism in lambs but macroscopically without detectable thyroid changes.

\section{Vplyv príjmu chlóru na niektoré morfometrické parametre štítnej žlazy u jahniat}

Morfometricky sme sledovali výšku epitelových buniek folikulov štítnej žlazy, priemer folikulov štítnej žlazy, frekvenciu kategórií výšky epitelových buniek a frekvenciu kategórií priemeru folikulov u dvoch skupín jahniat po štyroch týždňoch a po troch mesiacoch. Prvá skupina prijímala pitnú vodu, obsahujúcu chlór v koncentrácii $0,3 \mathrm{mg} \cdot \mathrm{l}^{-1}$ (skupina krátkodobého príjmu nízkej koncentrácie) počas štyroch týždňov. Druhá skupina prijímala pitnú vodu, obsahujúcu chlór v koncentrácii 1,8 $\mathrm{mg} \cdot \mathrm{l}^{-1}$ (skupina dlhodobého príjmu vysokej koncentrácie) počas troch mesiacov.

Zaznamenali sme významné $(\mathrm{P}<0,01)$ zvýšenie výšky epitelových buniek a významný ( $\mathrm{P}<0,01$ pre kategórie 3,1-4 a 4,1-5 $\mu \mathrm{m}$ ) presun frekvencie kategórií výšky buniek do vyšších velkostných skupín po príjme vody, obsahujúcej chlór v koncentrácii $0,3 \mathrm{mg} \cdot \mathrm{l}^{-1}$ počas štyroch týždňov a tiež významné $(\mathrm{P}<0,01)$ zvýšenie výšky epitelových buniek a významný ( $\mathrm{P}<0,01$ pre kategórie 4,1- 5 a 5,1-6 $\mu \mathrm{m}$ ) presun frekvencie kategórií výšky buniek do vyšších velkostných skupín po príjme vody, obsahujúcej chlór v koncentrácii $1,8 \mathrm{mg} \cdot \mathrm{l}^{-1}$ počas troch mesiacov v porovnaní s kontrolnými skupinami a kategóriami.

Priemer folikulov štítnej žlazy významne $(\mathrm{P}<0,01)$ poklesol a percento malých folikulov sa významne zvýšilo $(\mathrm{P}<0,01$ pre kategóriu 20,1-40 a $\mathrm{P}<0,05$ pre kategóriu 40,1-60 $\mu \mathrm{m})$ po príjme vody, obsahujúcej chlór $\mathrm{v}$ koncentrácii $1,8 \mathrm{mg} \cdot \mathrm{l}^{-1}$ počas troch mesiacov $\mathrm{v}$ porovnaní s kontrolnou skupinou a kontrolnými kategóriami.

Naše morfometrické výsledky poukazujú na interferenciu chlóru s metabolizmom štítnej žlazy u jahniat ale makroskopické zmeny štítnej žlazy sme nepozorovali.

\section{References}

ANKE, M., GROPPEL, B., BAUCH, K.-H. 1993: Iodine in the food chain. In: DELANGE, F., DUNN, J. T., GLINOER, D.: Iodine deficiency in Europe. New York, Plenum Press, pp. 151-157

BERCZ, J. P., GARNER L. 1991: Endocrine toxicity of drinking water disinfectants. II. Inhibition of hepatic 5' thyroxine deiodinase by halogenated nutrients. J. Amer. College Toxicol. 10: 533-539

BERCZ, J. P., JONES, L. L., HARRINGTON, R. M., BAWA, R., CONDIE, L. 1986: Mechanistic aspects of ingested chlorine dioxide on thyroid function: Impact of oxidants on iodine metabolism. Environ. Health Perspect. 69: 249-255

BERCZ, J. P., JONES, L. L., GARNER,, L., MURRAY, D., LUDWIG, D. A., BOSTON, J.1982: Subchronic toxicity of chlorine dioxide and related compounds in drinking water in the nonhuman primate. Environ. Health Perspect. 46: 47-55 
CAPEN, C. C., DeLELLIS, R. A., YARRINGTON, J. T. 1991: Endocrine System. In: HASCHEK, W. M., ROUSSEAUX, C. G.: Handbook of toxicologic pathology. San Diego, Acad. Press, pp. 675-760

DUMONT, J. E. 1993: Control of thyroid growth. In: DELANGE, F., DUNN, J. T., GLINOER, D.: Iodine deficiency in Europe. New York, Plenum Press, pp. 35-41

GAITAN, E. 1990: Goitrogens in food and water. Ann. Rev. Nutr. 10: 21-39

ORME, J., TAYLOR, D. H., LAURIE, K. D., BULL, R. J. 1985: Effects of chlorine dioxide on thyroid function in neonatal rats. J. Toxicol. Environ. Health 15: 315-322

PÍSAŘIIKOVÁ, B., HERZIG, I., ŘíHA, J. 1996: Anorganické anionty s možným strumigenním vlivem v pitných a napájecích vodách. Vet. Med. - Czech 41: 33-39

REVIS, N. W., McCAULEY, P., BULL, R., HOLDSWORTH, G. 1986: Relationship of drinking water disinfectants to plasma cholesterol and thyroid hormone levels in experimental studies. Proc. Natl. Acad. Sci 83: $1485-1489$

TRIOLA, M. F. 1989: Elementary statistics, 4th ed. Redwood City, Calif. The Benjamin / Cummings Publ. Comp. Inc. $784 \mathrm{p}$.

ZRƯNEK, A., KLÍMOVÁ, J., BÍLOVÁ, D. 1989: Rostlinné strumigeny ve vztahu ke zdraví hospodářskych zviřrat. Veterinářství 39: 483-485 